\title{
$\angle S$ Research Square \\ Characterization of a Novel Tombusviridae Species Isolated From Paris polyphylla var. yunnanensis
}

\section{Mingfu Zhao ( $\square$ zhaomingfu@163.com )}

Yunnan Agricultural University https://orcid.org/0000-0002-1186-7203

\section{Lu Chen}

Yunnan Agricultural University

\section{Rex Frimpong Anane}

Kunming Institute of Zoology Chinese Academy of Sciences

\section{Zhe Wang}

Yunnan Agricultural University

\section{Zeli Chen}

Yunnan Agricultural University

\section{Like Gao}

Yunnan Agricultural University

\section{Guosong Wen}

Yunnan Agricultural University

\section{Research Article}

Keywords: novel virus, Paris virus 2 (ParV2), Tombusviridae, Paris polyphylla var. yunnanensis

Posted Date: May 19th, 2021

DOI: https://doi.org/10.21203/rs.3.rs-511433/v1

License: (a) (1) This work is licensed under a Creative Commons Attribution 4.0 International License. Read Full License

Version of Record: A version of this preprint was published at Archives of Virology on August 13th, 2021. See the published version at https://doi.org/10.1007/s00705-021-05191-y. 


\section{Abstract}

A novel virus, Paris virus 2 (ParV2), was isolated from diseased Paris polyphylla var. yunnanensis, and its complete genome sequence was determined and analyzed. ParV2 is a positive-sense single-stranded RNA (+ssRNA) virus with a genome size of 4118 nucleotides. The ParV2 genome contains six putative open reading frames (ORFs) that encode proteins with predicted molecular weights of 40.14, 100.26, 7.31, 7.85, 26.09, and 8.77 kDa. The first ORF (ORF1) of ParV2 encodes a putative protein of $40.14 \mathrm{kDa}$ (p40, nt: 20-1096), whiles the second ORF (ORF2, 888 aa) containing the GDD motif encodes the highly conserved RNA-dependent RNA polymerase protein (RdRP, nt:20-2683, p100, $100.26 \mathrm{kDa}$ ) of viruses in the family Tombusviridae. Multiple sequence alignments analysis showed that the complete genome sequence of ParV2 shares 31.7-55.5\% nucleotide sequence identities with viruses in the family Tombusviridae. Ginger chlorotic fleck-associated tombusvirus (GCFaV-1,Accession No.QKE30557) had the highest sequence identity (55.5\%) with ParV2, and also shares 59.2\% RdRp and 34.9\% CP amino acid sequence identity with

GCFaV-1.Sequence comparisons and phylogenetic analysis of RdRp suggested that ParV2 is a novel member of the family Tombusviridae, and its closest known relative is GCFaV-1.

\section{Introduction}

Paris polyphylla var. yunnanensis is a perennial herb that belongs to the genus Paris of the family Trilliaceae. It is widely distributed in Yunnan province, China.Due to its wide medicinal applications, it is used as one of the raw materials for various Chinese patent medicines. The scarcity of wild natural resources and large market demand of Paris polyphylla var. yunnanensis as a result of its medicinal importance have led to the rapid development of its artificial planting industry - a major cause of the continual emergence of new diseases. Reports indicate that Paris mosaic necrosis virus (PMNV), Paris polyphylla virus X (PPVX), Pepper mild mottle virus (PMMoV), Cowpea aphid borne mosaic virus (CABMV), and Paris virus 1 (ParV1) infect and cause viral diseases in Paris polyphylla var. yunnanensis, leading to significant losses in plant yield ${ }^{[1-6]}$.

Viruses in the family Tombusviridae are positive-sense single-stranded RNA viruses that exhibit smooth or granular appearance with a diameter of 28-35 nm. The RNA of Tombusviridae is encapsulated in an icosahedral $(T=3)$ capsid that is composed of 180 identical protein subunits in three conformationally distinct states $(A, B, C)$. With the exception of Dianthoviruses whose genome is bipartite, all members of Tombusviridae have a non-segmented (monopartite) linear genome of about $3.7-4.8 \mathrm{~kb}$ in size. The Tombusviridae consist of 16 genera that is divided into three subfamilies. All members of this family are readily transmitted by mechanical inoculation and through plant material used for propagation or grafting, and both the virion and the genetic material alone are infective. Most Tombusviridae species can be transmitted through the soil either dependent on, or independent of, a biological vector. Although, members of Tombusviridae can either infect monocotyledonous or dicotyledonous plants, no species has been found to infect both. The experimental host range is wide, but the natural host range of individual virus species is relatively narrow. Typical characteristics of viral diseases caused by the viruses of Tombusviridae include mottling, crinkling, necrosis and deformation of leaf, and some infections are symptomless in their natural hosts. Although variability exists in the number and location of genes within members of the family, they all have a conserved organizational feature. This unifying feature is a highly conserved polymerase that contains the canonical "GDD" motif.

We previously reported a novel potyviruses, Paris virus 1 (ParV1), isolated from diseased Paris polyphylla var. yunnanensis leaves exhibiting mosaic and mottle symptoms ${ }^{[6]}$. In the present study, we identified and characterized 
the complete genome sequence of a novel virus (ParV2) infecting Paris polyphylla var. yunnanensis and confirmed its taxonomic and phylogenic relationship with other known viruses.

\section{Materials And Methods}

Diseased leaf samples exhibiting leaf mosaic and chlorotic symptoms, and suspected of viral infection (Fig. 1A) were sent to Oebiotech Co. Ltd (Shanghai, China) for high throughput sequencing (HTS) on the Illumina HiSeq 2500 platform. Total RNA was extracted from diseased leaf samples using OMEGA® Plant RNA Kit (TaKaRa Bioengineering, Dalian) according to manufacturer's instructions. To confirm the sequencing results, total RNA isolated from virus-infected leaves was reverse transcribed into cDNA using the ABM® 5X All-In-One RT MasterMix (Macklin Biochemical Co. Ltd, Shanghai). Reverse Transcription-Polymerase Chain Reaction (RT-PCR) was performed using 2xTaq PCR MasterMix (Biomed Gene Technology Co. Ltd., Beijing, China) and the specific primers ParV2:1-13 F/R designed based on the sequence of the assembled contigs to confirm the presence of the virus, and also amplify the whole genome sequence. The 5' and 3' terminals of the viral genome were amplified using 5' RACE and 3' RACE kit (Sangon Biotech, Shanghai; order No. B605102 and B605101) and specific reverse transcription primers 2R, R1, R2, F1 and F2. The sequences of all primers used in this study have been listed in Supplementary Tables S1 and S2. To confirm the classification status of the virus and determine its relationship with other viruses, ORFs in the viral genome sequence and protein molecular masses were predicted by NCBI ORF finder (www.ncbi.nlm.nih.gov/projects/gorf). The nucleotide (nt) and protein amino acid (aa) sequences of related viruses were retrieved from NCBI database and used for sequence alignments. Sequence identities were calculated using the ClustaIW algorithm in BioEdit 7.0 program. Phylogenetic relationships between the novel virus and related viruses were determined using the Neighbor-Joining method (NJ) within the MEGA7.0 program with replicas bootstrapped to 1000.

\section{Results}

Raw reads were processed to remove adaptor and low-quality reads. The transcript sequences were de novo assembled into contigs using paired-end splicing method in the Trinity program. BLASTx analysis of assembled contigs revealed that one contig consisting of $4118 \mathrm{nt}$ was most similar to the genome sequences of viruses of the family Tombusviridae. This result suggests that a Tombusviridae species could be responsible for the virus-diseaselike symptoms in diseased Paris polyphylla var. yunnanensis plants. Sequencing of RT-PCR products of the total RNA isolated from virus-infected Paris polyphylla var. yunnanensis leaves produced a sequence of $4118 \mathrm{nt}$ that includes the 5' and 3' RACE data for the isolated virus which was deposited in the GenBank database under the accession number MW423699.

The complete RNA genome of ParV2 (MW423699) consists of 4,118 nt, and contains six ORFs, 5'-UTR (19 nt) and 3'UTRs (359 nt) (Fig. 1B). The first ORF of the ParV2 putatively encodes a P40 protein (nt:20-1096) of $40.14 \mathrm{kDa}$. If the amber codon UAG (nt:1094-1096) is readthrough, the ORF2 (nt:20-2683, 888 aa) predicted to encode a $100.26 \mathrm{kDa}$ RNA-dependent RNA polymerase (RdRp, P100) protein is continuously translated. This ParV2 RdRp is similar to the highly conserved RdRp of members of the family Tombusviridae that contains a conserved ${ }^{684} \mathrm{GDD}^{686}$ motif ${ }^{[7-9]}$. The ParV2 sequence 5'AAA UAG GGG 3' (nt:1091-1099) surrounding the amber stop codon is consistent with the proposed relative efficiency of readthrough sequences (A/C/U) (A/U) AUAG (G/C) (G/A). This amber stop codon surrounded sequence of ParV2 is $100 \%$ identical to the corresponding sequence present in the members of Tombusviridae ${ }^{[10-12]}$.ORF3 (nt:2641-2844,68aa,7.31kDa) encodes the putative movement protein 1 (MP1, P7), that may be involved in virus movement, contains the FNF motif (at the C-terminus) that is conserved within the putative 
movement proteins of Carmoviruses, Machlomoviruses and Panicoviruses ${ }^{[13,14]}$, an indication that ParV2 is a member of the Tombusviridae. As seen in some animal and plant viruses whose initiation codons for mRNA translation are non-AUG start codons CUG, ACG and GUG ${ }^{[13,15,16]}$, the ORF4 (nt:2844-3062,72aa,7.85kDa,P8) encoding the putative movement protein 2 (MP2) of ParV2 has the non-canonical start codon ${ }^{2844} A C G{ }^{2846}$. The last adenine base of ORF3 stop codon is the first base of ORF4 start codon. Similarly, the MP2 of panicoviruses such as Cocksfoot mild mosaic virus (CMMV), Panicum mosaic virus (PMV), Thin paspalum asymptomatic virus (TPAV) and Bermuda grass latent virus (BGLV) initiates with CUG, GUG, CUG and CUG start codons respectively ${ }^{[15,17,18]}$. ORF5 (nt:3031-3759, $243 \mathrm{aa}$ ) encodes the $26.09 \mathrm{kDa}$ coat protein (CP, P26). In addition to pre-readthrough and readthrough proteins (RdRp), MP1, MP2, CP, ParV2 also contains ORF6 (nt:3207-3434,75aa) that is embedded within the CP gene, and encodes the P9 (accessory protein) of $8.77 \mathrm{kDa}$. The existence of Tombusviridae motifs and other Tombusviridae-specific features in ParV2 genome suggest that ParV2 is evolutionally close to viruses in this family, and that ParV2 is a member of the family Tombusviridae. 
Table 1

Nucleotide (nt) and amino acid (aa) sequence identities of ParV2 and other members of a few genus within Tombusviridae.

\begin{tabular}{|c|c|c|c|c|c|c|c|c|}
\hline \multirow[t]{2}{*}{$\begin{array}{l}\text { Genus of } \\
\text { Tombusviridae }\end{array}$} & \multirow[t]{2}{*}{ Virus Name } & \multirow[t]{2}{*}{$\begin{array}{l}\text { Accession } \\
\text { number }\end{array}$} & \multirow{2}{*}{$\begin{array}{l}\text { Viral } \\
\text { genome } \\
\text { sizes(nt) }\end{array}$} & \multirow{2}{*}{$\begin{array}{l}\text { Sequence } \\
\text { identity (\%) } \\
\text { complete } \\
\text { genomes(nt) }\end{array}$} & \multicolumn{4}{|c|}{$\begin{array}{l}\text { Sequence identity (\%)for } \\
\text { encoded proteins }\end{array}$} \\
\hline & & & & & RdRP & MP1 & MP2 & $\mathrm{CP}$ \\
\hline Unclassified & $\begin{array}{l}\text { Ginger } \\
\text { chlorotic fleck- } \\
\text { associated } \\
\text { tombusvirus }\end{array}$ & MN581046 & 4143 & 55.5 & 59.2 & 42.8 & 47.2 & 34.9 \\
\hline \multirow[t]{5}{*}{ Panicovirus } & $\begin{array}{l}\text { Bermuda } \\
\text { grass latent } \\
\text { virus }\end{array}$ & NC-032405 & 4044 & 43.7 & 40.2 & 23.2 & 18.6 & 19.8 \\
\hline & $\begin{array}{l}\text { Thin } \\
\text { paspalum } \\
\text { asymptomatic } \\
\text { virus }\end{array}$ & JX848616 & 4193 & 43.5 & 38.5 & 19.1 & 24.0 & 21.2 \\
\hline & $\begin{array}{l}\text { Thin } \\
\text { paspalum } \\
\text { asymptomatic } \\
\text { virus }\end{array}$ & NC-021705 & 4195 & 41.9 & 38.5 & 20.5 & 24.0 & 18.1 \\
\hline & $\begin{array}{l}\text { Panicum } \\
\text { mosaic virus }\end{array}$ & MH885652 & 4324 & 40.6 & 36.3 & 17.8 & 25.3 & 23.6 \\
\hline & $\begin{array}{l}\text { Cocksfoot } \\
\text { mild mosaic } \\
\text { virus }\end{array}$ & NC-011108 & 4198 & 42.4 & 38.6 & 24.3 & 16.0 & 24.2 \\
\hline \multirow[t]{5}{*}{ Pelarspovirus } & $\begin{array}{l}\text { Jasmine } \\
\text { mosaic- } \\
\text { associated } \\
\text { virus } 2\end{array}$ & MG958506 & 3885 & 31.7 & 31.1 & 12.8 & 13.0 & 7.7 \\
\hline & $\begin{array}{l}\text { Jasmine } \\
\text { mosaic- } \\
\text { associated } \\
\text { virus } 2\end{array}$ & MF991300 & 3975 & 32.5 & 30.2 & 11.4 & 11.9 & 8.0 \\
\hline & $\begin{array}{l}\text { Jasmine virus } \\
\mathrm{H}\end{array}$ & MH231176 & 3867 & 33.4 & 30.4 & 11.4 & 10.8 & 8.0 \\
\hline & $\begin{array}{l}\text { Jasmine virus } \\
\mathrm{H}\end{array}$ & MH231180 & 3867 & 33.4 & 30.2 & 12.8 & 11.9 & 8.3 \\
\hline & $\begin{array}{l}\text { Jasmine } \\
\text { mosaic- } \\
\text { associated } \\
\text { virus } 1\end{array}$ & MG958505 & 3867 & 32.5 & 29.8 & 11.4 & 10.8 & 8.6 \\
\hline \multirow[t]{2}{*}{ Machlomovirus } & $\begin{array}{l}\text { Maize } \\
\text { chlorotic } \\
\text { mottle virus }\end{array}$ & MF510225 & 4439 & 38.9 & 38.9 & 25.7 & 14.8 & 17.0 \\
\hline & $\begin{array}{l}\text { Maize } \\
\text { chlorotic } \\
\text { mottle virus }\end{array}$ & MF510235 & 4439 & 39.1 & 38.9 & 25.7 & 14.8 & 17.0 \\
\hline
\end{tabular}




\begin{tabular}{|c|c|c|c|c|c|c|c|c|}
\hline \multirow[t]{2}{*}{$\begin{array}{l}\text { Genus of } \\
\text { Tombusviridae }\end{array}$} & \multirow[t]{2}{*}{ Virus Name } & \multirow[t]{2}{*}{$\begin{array}{l}\text { Accession } \\
\text { number }\end{array}$} & \multirow{2}{*}{$\begin{array}{l}\text { Viral } \\
\text { genome } \\
\text { sizes(nt) }\end{array}$} & \multirow{2}{*}{$\begin{array}{l}\text { Sequence } \\
\text { identity (\%) } \\
\text { complete } \\
\text { genomes(nt) }\end{array}$} & \multicolumn{4}{|c|}{$\begin{array}{l}\text { Sequence identity (\%)for } \\
\text { encoded proteins }\end{array}$} \\
\hline & & & & & RdRP & MP1 & MP2 & $\mathrm{CP}$ \\
\hline \multirow[t]{2}{*}{ Betacarmovirus } & $\begin{array}{l}\text { Turnip crinkle } \\
\text { virus }\end{array}$ & MK301398 & 4061 & 33.8 & 30.6 & 15.0 & 7.6 & 10.1 \\
\hline & $\begin{array}{l}\text { Japanese iris } \\
\text { necrotic ring } \\
\text { virus }\end{array}$ & NC-002187 & 4041 & 37.8 & 26.3 & 10.5 & 13.6 & 10.1 \\
\hline \multirow[t]{3}{*}{ Gammacarmovirus } & $\begin{array}{l}\text { Melon } \\
\text { necrotic spot } \\
\text { virus }\end{array}$ & AY122286 & 4271 & 32.2 & 29.3 & 15.7 & 23.6 & 9.3 \\
\hline & $\begin{array}{l}\text { Pea stem } \\
\text { necrosis virus }\end{array}$ & NC-004995 & 4048 & 32.1 & 30.7 & 15.7 & 18.0 & 8.1 \\
\hline & $\begin{array}{l}\text { Cowpea } \\
\text { mottle virus }\end{array}$ & NC-003535 & 4029 & 37.3 & 29.0 & 18.3 & 7.8 & 8.7 \\
\hline \multirow[t]{2}{*}{ Alphacarmovirus } & $\begin{array}{l}\text { Angelonia } \\
\text { flower break } \\
\text { virus }\end{array}$ & NC-007733 & 3962 & 31.7 & 29.9 & 17.6 & 13.4 & 9.3 \\
\hline & $\begin{array}{l}\text { Pelargonium } \\
\text { flower break } \\
\text { virus }\end{array}$ & NC-005286 & 3923 & 32.2 & 29.4 & 18.0 & 11.1 & 8.5 \\
\hline Gallantivirus & $\begin{array}{l}\text { Galinsoga } \\
\text { mosaic virus }\end{array}$ & NC-001818 & 3803 & 34.4 & 29.3 & 16.9 & 14.8 & 9.7 \\
\hline
\end{tabular}

Further pairwise comparison of the complete genome nucleotide sequence and ORFs of ParV2 indicated that ParV2 share 31.7-55.5\% complete genome nt, 26.3-59.2\% RdRp, 10.5-42.8\% MP1, 7.6-47.2\% MP2, and 7.7-34.9\% CP aa identities with 21 virus isolates of the family Tombusviridae (Table 1). The highest identity (55.5\%) was seen with GCFaV-1 (QKE30557) followed by members of the genus Panicovirus (40.6-43.7\%).Again, the highest aa identities of the individual proteins of ParV2 were seen with GCFaV-1, followed by Machlomovirus (RdRp and MP1) or Panicovirus (MP2 and CP). These results indicate that ParV2 is a member of the Tombusviridae, although it may not have all the characteristics of specific genera within the family Tombusviridae.

To determine the phylogenetic status of ParV2 and the evolutionary relationship between ParV2 and other viruses of the family Tombusviridae, phylogenetic tree was constructed using the aa sequences of RdRp protein (a reliable indicator for virus taxonomy).It can be seen from the tree that ParV2 clustered with the unassigned/unclassified GCFaV-1, and machlomoviruses and panicoviruses of the subfamily Procedovirinae. GCFaV-1 is the closest known relative of ParV2 (Fig. 2). It can be inferred from the tree that ParV2 shares a recent common ancestor with viruses of the genera Machlomovirus and Panicovirus. ParV2 and GCFaV-1 diverged from the branch that gave rise to the genera Machlomovirus and Panicovirus (Fig. 2). It can be concluded that Parv2 is a member of the subfamily Procedovirinae of the family Tombusviridae, although it couldn't be allocated to any Procedovirinae-specific genera. These results confirm our pairwise comparison, and genome analyses results which indicated that ParV2 is a novel member of the family Tombusviridae.

\section{Discussion}


In this study, we identified and characterized a novel plant virus that belongs to the family Tombusviridae, and is tentatively named Paris virus 2. ParV2 has a typical Tombusviridae genome organization ${ }^{[19-22]}$. Multiple sequence alignments analysis showed that ParV2 share 31.7-55.5\% nt sequence identities with members of the family Tombusviridae. Although, ParV2 clustered with viruses in the genera Machlomovirus and Panicovirus, the closest known relative of ParV2 is the unclassified/unassigned GCFaV-1, which showed the highest sequence similarity with ParV2. Similar to machlomoviruses and panicoviruses genomes that encode a 7-8 kDa MP1 and 6-9 kDa MP2, ParV2 genome also encode an MP1 and MP2 of 7.31kDa and 7.85kDa respectively. In contrast, genomes of tombusviruses and aureusviruses encode a conserved 22-27 kDa MP, whiles that of dianthoviruses encode another type of MP of about $34 \mathrm{kDa}$. These results indicate the relationship of ParV2 with viruses of the genera Machlomovirus and Panicovirus.

One of two distinct groups of CP subunit always exist in the capsids of Tombusviridae species. In one group of genera (Machlomovirus, Necrovirus and Panicovirus) that have structured CP lacking P domain, the CP subunit ranges in size of $25-30 \mathrm{kDa}$, whiles in the other group of genera with a CP-containing $\mathrm{P}$ domain, the CP subunit ranges in size of $37-48 \mathrm{kDa}$. Our comparative sequence analysis results revealed that CP of ParV2 has a size of $26.09 \mathrm{kDa}$, that is similar to the structured CP of the genera Machlomovirus, Necrovirus and Panicovirus. The genomic RNA of Machlomovirus and Panicovirus are $4.4 \mathrm{~kb}$ (encoding four ORFs) and $4.3 \mathrm{~kb}$ (encoding five ORFs) respectively. In contrast, ParV2 and GCFaV-1 have genomic RNA of $4.1 \mathrm{~kb}$ that encode six ORFs. These data suggest that although ParV2 and GCFaV-1 share various characteristics with Machlomovirus and Panicovirus species, ParV2 and GCFaV-1 belong to a distinct genus. These results also confirm our phylogenetic data that indicate that GCFaV-1 is the closest known relative of ParV2, and that ParV2 and GCFaV-1 share a recent common ancestor with the genera Machlomovirus and Panicovirus.

Taken together, ParV2 should be considered a new species of the family Tombusviridae, and its taxonomic status should be further studied. We therefore propose that ParV2 and GCFaV-1 should be assigned to a new genus within the subfamily Procedovirinae in the family Tombusviridae. In addition to the viral-symptoms, there were obvious insect bites on the infected leaves of Paris polyphylla var. yunnanensis. It is possible that the virus infected the plants through insect transmission. This is the first report of a virus of Tombusviridae infecting Paris polyphylla var. yunnanensis. As a new virus, further studies are required to ascertain its method of transmission and possible vector.

\section{References}

1. Lu H, Xu JH, Chen RP (2006) Resource status and protection countermeasures of genus Paris plant. J Yunnan Univ Nat Sci Edn. 28(S1):307-310 4. Meng FY, Wang LY, Feng CQ (2005) Advances in research on introduction and domestication of Paris polyphylla var. yunnanensis. Chin Herb Med. 36(7):1102-1104.

2. Meng FY, Wang LY, Feng CQ (2005) Advances in research on introduction and domestication of Paris polyphylla yunnanensis. Chin Herb Med. 36(7):1102-1104.

3. Lan P, Zhao J, Zhou Y et al (2018) Complete genome sequence of Paris mosaic necrosis virus, a distinct member of the genus Potyvirus. Arch Virol 163(3):787 .

4. Dong JH, Ding M, Fang Q, Luo YQ, Zhang ZK, Li Z, Yang B, Li XM (2007) Molecular identifcation of a Potexvirus isolate infecting Pairs polyphylla Yunnanensis and analysis of 3'terminal sequence. Acta Phytopathologica Sin 37(3):237-241.

5. Wen GS, Yang LY, Anane RF, Chen ZL, Yang YH, Chen L, Sun Y, Zhao MF (2019) First report of Pepper mild mottle virus in Pairs polyphylla Yunnanensis in China. Plant Dis 103(12):3289. 
6. Chen L , Anane R F , Wang Z, et al. Whole-genome sequence analysis of paris virus 1: a novel member of the genus Potyvirus infecting Paris polyphylla yunnanensis[J]. Archives of Virology, 2020, 165(3).

7. Mollov, D., Lockhart, B., \& Zlesak, D.C. (2013). Complete nucleotide sequence of Rosa rugosa leaf distortion virus, a new member of the family Tombusviridae. Archives of Virology, 158, 2617-2620.

8. Tahir, M.N., Lockhart, B., Grinstead, S., \& Mollov, D. (2017). Characterization and complete genome sequence of a panicovirus from Bermuda grass by high-throughput sequencing. Archives of Virology, 162, 1099-1102.

9. Koonin EV, Dolja VV (1993) Evolution and taxonomy of positive-strand RNA viruses: implications of comparative analysis of amino acid sequences. Crit Rev Biochem Mol Biol 28:375-430.

10. Skuzeski, J.M., Nichols, L.M., \& Gesteland, R.F. (1990). Analysis of leaky viral translation termination codons in vivo by transient expression of improved/I-glucuronidase vectors. Plant Molecular Biology, 15, 65-79.

11. Guilley, H., Carrington, J.C., Balazs, E., Jonard, G., Richards, K., \& Morris, T.J. (1985). Nucleotide sequence and genome organization of carnation mottle virus RNA. Nucleic Acids Research. 13, 6663-6667.

12. Nutter, R.C., Scheets, K., Panganiban, L.C., \& Lommel, S.A. (1989). The complete nucleotide sequence of the maize chlorotic mottle virus genome. Nucleic Acids Research, 17, 3163-3177.

13. Turina M, Maruoka M, Monis J, Jackson AO, Scholthof KB (1998) Nucleotide sequence and infectivity of a fulllength cDNA clone of Panicum mosaic virus. Virology 241:141-155.

14. Bhat, A. I.,Naveen,K. P., Pamitha, N. S.,\& Pant, R. P.. (2020). Association of two novel viruses with chlorotic fleck disease of ginger. Annals of Applied Biology.

15. Scheets, K., Jordan, R., White, K.A., \& Hernandez, C. (2015). Pelarspovirus, a proposed new genus in the family Tombusviridae. Archives of Virology, 160, 2385-2393.

16. Riechmann JL, Ito T, Meyerowitz EM (1999) Non-ATG initiation of AGAMOUS mRNA translation in Arabidopsis thaliana.Mol Cell Biol 19:8505-8512.

17. Muhammad N. Tahir, Ben Lockhart, Samuel Grinstead, \& Dimitre Mollov. (2017). Characterization and complete genome sequence of a panicovirus from bermuda grass by high-throughput sequencing. Archives of Virology.

18. Chowda-Reddy, R. V. , Palmer, N. A. , Edme, S. , Sarath, G. , \& Tatineni, S. . (2018). A two-amino acid difference in the coat protein of satellite panicum mosaic virus isolates is responsible for differential synergistic interactions with panicum mosaic virus. Molecular Plant-Microbe Interactions, 32(4).

19. Hacker, D.L., Petty, I.T.D., Wie, N., Morris, T.J., 1992. Turnip crinkle virus genes required for RNA replication and virus movement. Virology 186, 1-8.

20. Morris, T.J., Carrington, J.C., 1988. Carnation mottle virus and viruses with similar properties. In: Koenig, R. (Ed.), The Plant Viruses, vol. 3. Plenum Press, New York,pp. 73-112.

21. Robertson, N.L., Cote, F., Pare, C., Leblanc, E., Bergeron, M.G., Leclerc, D., 2007. Complete nucleotide sequence of Nootka lupine vein-clearing virus. Virus Genes 35,807-814.

22. Argos, P., 1988. A sequence motif in many polymerases. Nucleic Acids Res. 16,9909-9916.

\section{Supplementary Files}

This is a list of supplementary files associated with this preprint. Click to download.

- Parisvirus2.txt

- Supplementarymaterial.docx 